\title{
心不全患者に対する病院の薬剤師と 保険薬局の薬剂師による協働介入の効果
}

\author{
高井 靖*，梶間勇樹 \\ 三重ハートセンター薬局 \\ Effects of Cooperation Intervention by \\ Hospital Pharmacists and Community Pharmacists
}

\author{
Yasushi Takai* and Yuuki Kajima \\ Department of Pharmacy, Mie-Heart Center Hospital \\ $\left[\begin{array}{l}\text { Received December 18, } 2019 \\ \text { Accepted March 23, } 2020\end{array}\right]$
}

In this research, we examined the effects of collaborative intervention by pharmacists in hospitals and insurance pharmacies on the quality of life (QOL) and medication adherence of heart failure patients. Heart failure inpatients were assigned to the collaborative intervention group (Group A) and the control group (Group B), with each group containing 35 subjects. Both groups were examined 12 months after they were admitted to hospital, and the conditions at the time of admission were used as the baseline. The primary endpoint was QOL, which was evaluated by the Minnesota Living with Heart Failure (MLHF) scale, and the secondary endpoints were medication adherence and prescription complexity index, which were assessed using the medication regimen complexity index (MRCI) and the Morisky Medication Adherence Scale (MMAS-4), respectively. The number of target patients that could be analyzed was 31 in group A (18 men and 13 women with an average age of $78.1 \pm 9.9$ years), and 29 in group B (17 men and 12 women with an average age of $79.6 \pm 8.1$ years). The QOL at the time of admission and discharge from the hospital was significantly improved in group A and B $(P<0.05)$. MMAS-4 improved significantly in group A $(P<0.05)$ but did not change significantly in group B. MRCI was significantly increased in group B $(P<0.05)$. It is suggested that the intervention by pharmacists in hospitals and insurance pharmacy pharmacists for heart failure patients may have an impact on improving the quality of life.

Key words — heart failure, quality of life (QOL), Minnesota Living with Heart Failure (MLHF), medication regimen complexity index (MRCI), Morisky Medication Adherence Scale (MMAS-4), collaborative intervention

\section{緒 言}

日本は, 2013 年に世界に先駆けて高齢化率は $25 \%$ となり，超高齢社会を迎えている。厚生労働 省は，2025年を目途に可能な限り住み慣れた地 域で自分らしい暮らしを人生の最期まで続けるこ とができるよう, 「地域包括ケアシステム」の構 築を進めている. 入院から在宅に移行する患者に とって継続した薬物療法は, 再入院リスクを減ら す重要な鍵になる。

慢性心不全患者の治療目標は,「予後の改善」 と「生活の質（quality of life: QOL）の改善」で ある。慢性心不全患者は, 入退院を繰り返すこと が多く, 1 年後の再入院は $17.5 \%, 3$ 年後の再入 院は $25.5 \%$ であったという報告がある. ${ }^{1)}$ また心 不全増悪による再入院の要因として, 治療薬服用 の不徹底が $11 \%$ であったという報告があり, ${ }^{2)}$ 服 薬アドヒアランスを良好に維持することは心不全 患者の再入院の予防のために必要である.我々は, 先行研究において病院薬剤師の外来受診時におけ る継続した介入は，服薬アドヒアランスを改善す

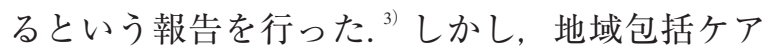

\footnotetext{
*\%515-0302 三重県多気郡明和町大字大淀2227-1
} 
システムでは病院の薬剤師と保険薬局の薬郕師が 連携することが必要となるが，この連携による患 者アウトカムを評価した報告は先行研究も含めて 散見されない，そこで，本研究は心不全患者を対 象として, 病院の薬剮師と保険薬局の薬郕師が退 院後も協働して介入した効果を QOL と服薬アド ヒアランスで検証した。

\section{方 法}

\section{1. 対象患者と協働介入}

この調查は，当院に入院した心不全患者を対象 に, 2018 年 4 月 1 日〜 2019 年 6 月 30 日の期間で 実施した，対象患者は，本研究に参加する保険薬 局はあらかじめ決められており，その該当する薬 局をかかりつけ薬局としている患者について, 研 究説明を行い口頭で同意を得た患者とした。登録 人数は先行研究 (各群 25 例) と当院の心不全の 症例数を考慮して各群 35 名とした．封筒法によ り, 退院後も当院薬剂部と保険薬局で協働介入を する群（A 群）と今まで通りに保険薬局で投薬 を受ける群（B 群）に割り付けた。なお，両群と も認知症患者と家族を含めた介護者による服薬管 理を受けている患者および末期重症患者は対象患 者から除外した。 そして, A 群については, 退院 時サマリーを作成して保険薬局の薬剤師に FAX などで入院中の情報共有を行った，保険薬局の薬 剂師は A 群の該当患者が来局した際にあらかじ め取り決めておいた介入項目に従ってチェックを 行い（表 1），6力月後に定期報告を行い，その 他は何かイベントがあれば病院の薬剤師にトレー シングレポートとして FAX で情報提供をするこ とと, さらに必要に応じて病院の薬郕師と協議を 行い，病院の医師またはかかりつけの医師に処方 提案を行った。

\section{2. 調査デザインと評価項目}

$\mathrm{A}$ 群と $\mathrm{B}$ 群について入院時をべースラインと して, 退院 12 力月後と比較した。患者背景は, 年齢, 性別, 心不全治療薬である。主要評価項目 は，患者 QOLを Minnesota Living with Heart Failure (MLHF) 質問票で評価した. ${ }^{4}$ 副次評価項目は,
表 1 協働介入

\begin{tabular}{|c|}
\hline 介入項目 \\
\hline 薬物治療への介入 \\
\hline 1）用法・用量, 効能効果のチェック \\
\hline 2）副作用モニタリング \\
\hline 3）相互作用チェック \\
\hline 4）重複投与チェック \\
\hline 5）薬効評価 \\
\hline 6）腎障害時の投与量チェック \\
\hline 7）採血依頼 \\
\hline 8）バイタルサイン・フィジカルアセスメント \\
\hline 9）処方提案 \\
\hline $\begin{array}{l}\text { 服薬アドヒアランスへの介入 } \\
\end{array}$ \\
\hline 1）服薬状況の把握，服薬管理能力の評価 \\
\hline 2) 服薬数を減らす \\
\hline 3）服用方法の簡素化 \\
\hline 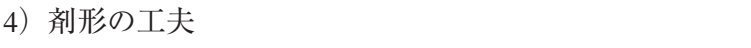 \\
\hline 5） 1 包化調剂, 服薬カレンダー, お薬ケース \\
\hline 6）介護者との連携 \\
\hline $\begin{array}{l}\text { 患者指導への介入 } \\
\end{array}$ \\
\hline 1）疾患に対する理解，薬物治療が必要な理由の理解 \\
\hline $\begin{array}{l}\text { 2) 薬物に対する知識 (投与目的, 用法 - 用量, 効能効果, } \\
\text { 副作用, 注意事項) }\end{array}$ \\
\hline 3）動機づけ \\
\hline
\end{tabular}

服薬アドヒアランス (Morisky Medication Adherence Scale: MMAS-4 で評価), ${ }^{5}$ 服用薬剂数, 処方の複 雑指数 (medication regimen complexity index: MRCI で評価）である. ${ }^{6}$ 入院時調查はベッドサイドで聞 き取りを行い, 12 カ月後については, 両群とも定 期診察前にそれぞれ聞き取りを行った.

\section{MLHF 質問票}

この質問票は，心不全の症状やそれにともなう 活動制限が心不全患者の生活の質を低下させると いう視点で，心不全患者自身がどのように認識し ているか質問している。この質問票の評価は 21 項目の質問からなり，項目ごとに「いいえ まあ 非常に困る」の段階を 0 5 のスコア範囲 で示し，その合計スコア（0１05）で QOLを評 価するものである（表 2)，高スコアほど心不全 関連 QOL の低下を示すものである.

\section{MMAS-4 と MRCI}

MMAS-4 は患者自身の認識により服薬行動を 見ることができる尺度である，本調查では神島ら の研究報告を参考に行った。 ${ }^{7}$ 具体的には，「薬を 
表 2 MLHF 質問票と結果

\begin{tabular}{|c|c|c|c|c|}
\hline \multirow{2}{*}{ 質問 } & \multicolumn{2}{|c|}{ A 群 } & \multicolumn{2}{|c|}{ B 群 } \\
\hline & 入院時 & 12 力月後 & 入院時 & 12 力月後 \\
\hline 1 足の浮腫（むくみ） & $3.16 \pm 1.18$ & $2.32 \pm 0.83$ & $2.68 \pm 0.54$ & $2.17 \pm 0.41$ \\
\hline 2 日中, 椅子に掛けたり, 横になって休むことがある & $3.68 \pm 0.54$ & $3.16 \pm 0.77$ & $2.52 \pm 0.57$ & $2.55 \pm 0.57$ \\
\hline 3 歩いたり，階段を昇るのがしんどい & $3.32 \pm 0.83$ & $3.35 \pm 0.87$ & $2.66 \pm 0.52$ & $2.69 \pm 0.54$ \\
\hline 4 家事や庭仕事がしんどい & $1.84 \pm 1.18$ & $1.84 \pm 1.18$ & $2.17 \pm 0.41$ & $2.17 \pm 0.41$ \\
\hline 5 外出するのがしんどい & $3.32 \pm 0.54$ & $3.35 \pm 0.55$ & $2.34 \pm 0.54$ & $2.34 \pm 0.54$ \\
\hline 6 夜, 熟睡できない & $2.00 \pm 1.26$ & $2.00 \pm 1.26$ & $2.00 \pm 0.63$ & $2.03 \pm 0.63$ \\
\hline 7 友達や家族と一緒に何かをすることが難しい & $2.68 \pm 0.83$ & $2.68 \pm 0.83$ & $2.17 \pm 0.41$ & $2.17 \pm 0.41$ \\
\hline 8 働いて収入を得ることが難しい & $2.16 \pm 0.97$ & $2.16 \pm 0.97$ & $2.34 \pm 0.54$ & $2.34 \pm 0.54$ \\
\hline 9 娛楽, スポーツ, または趣味を楽しむのが難しい & $2.16 \pm 0.97$ & $2.16 \pm 0.97$ & $2.17 \pm 0.41$ & $2.17 \pm 0.41$ \\
\hline 10 性生活（セックス）が困難である & $0.00 \pm 0.00$ & $0.00 \pm 0.00$ & $0.34 \pm 0.82$ & $0.34 \pm 0.82$ \\
\hline 11 好きな食べ物を食べる量が減った & $2.45 \pm 0.51$ & $2.52 \pm 0.57$ & $2.66 \pm 0.84$ & $2.66 \pm 0.84$ \\
\hline 12 息切れがする & $3.52 \pm 0.57$ & $2.68 \pm 0.54$ & $3.00 \pm 0.63$ & $2.66 \pm 0.52$ \\
\hline 13 疲れやすい, だるい, 気力がないと感じる & $3.32 \pm 0.54$ & $3.00 \pm 0.89$ & $3.34 \pm 0.54$ & $3.31 \pm 0.48$ \\
\hline 14 入院 & $2.68 \pm 1.77$ & $2.68 \pm 1.77$ & $3.52 \pm 0.57$ & $3.52 \pm 0.57$ \\
\hline 15 医療費の支払い & $1.84 \pm 1.71$ & $1.84 \pm 1.71$ & $3.52 \pm 0.57$ & $3.52 \pm 0.57$ \\
\hline 16 治療による副作用 & $0.52 \pm 0.57$ & $0.52 \pm 0.57$ & $0.83 \pm 0.41$ & $0.83 \pm 0.41$ \\
\hline 17 自分は家族や友達に負担をかけていると思う & $3.32 \pm 0.54$ & $3.32 \pm 0.54$ & $3.83 \pm 0.41$ & $3.83 \pm 0.41$ \\
\hline 18 生活が自分の思う通りにならないと感じる & $2.81 \pm 0.78$ & $2.84 \pm 0.77$ & $3.17 \pm 0.41$ & $3.21 \pm 0.49$ \\
\hline 19 不安 & $2.29 \pm 0.53$ & $2.32 \pm 0.54$ & $2.83 \pm 0.41$ & $2.86 \pm 0.44$ \\
\hline 20 集中力が低下し, 物が思い出せない & $2.32 \pm 1.53$ & $2.35 \pm 1.52$ & $1.66 \pm 0.77$ & $1.69 \pm 0.85$ \\
\hline 21 気分が落ち込む（憂椢になる） & $2.65 \pm 0.83$ & $2.68 \pm 0.83$ & $2.17 \pm 0.41$ & $2.17 \pm 0.41$ \\
\hline
\end{tabular}

(平均土標準偏差). MLHF: Minnesota Living with Heart Failure.

飲み忘れたことがある」「薬を飲む時を忘れたこ とがある」「調子がよいと薬を飲むことをやめる ことがある」「体調悪いと薬を飲むことをやめる ことがある」の 4 項目に対して，「はい/いいえ」 で回答し，「はい」を 1 点,「いいえ」を 0 点とし て加算した合計点で評価した。

MRCI は投与レジメンいわゆる処方の複雑さを 定量化するためのツールである．大きく 3 つのセ クションからなる。 セクション $\mathrm{A}$ (剂形) は，投 与経路（経口，局所，点眼，点鼻等）とその剤形 (錠剂，液剂，スプレー等）からなる。セクショ ン B (投与頻度) は， 1 日の投与頻度やタイミン グからなる。 セクションC（投与に必要となる追 加条件) は, 漸減, 漸増, 食事との関連, 粉砕な どからなる。これらのセクションごとに細かな チェック項目が 65 項目あり, それぞれの項目は 重み付けによる点数配分がされている. 合計スコ アが大きいほど，より複雑なレジメンであること を示す。

\section{5. 統計解析}

MLHF, MMAS-4, 服用薬剂数, MRCIに対する 協働介入効果については, 従属变数を介入 12 力月 後の MLHF, MMAS-4, 服用薬剂数, MRCI, 独立 変数を群 (A 群，B 群)，それぞれ介入前の MLHF, MMAS-4, 服用薬剂数, MRCI とする analysis of covariance（ANCOVA）にて検証した. ANCOVA を用いた理由は $\mathrm{A}$ 群と $\mathrm{B}$ 群の介入前の従属変数 の差を補正するためである。また A 群と B 群の介 入前後の従属変数の平均值の差に Paired $t$-test を適 用し, 介入前後の変化を検証した。統計的有意性 検定の有意水準は 0.05 とした。統計解析は IBM SPSS Statistics24（IBM Japan, Ltd, Tokyo）にて実 施した.

\section{6. 倫理委員会}

本研究は,「人を対象とする医学系研究に関す る倫理指針」を遵守して実施し, 医療法人三重八ー トセンターの倫理委員会にて承認を得て実施した （承認番号 2018-08-117）。 


\section{結＼cjkstart果}

\section{1. 患者背景と調査項目}

$\mathrm{A}$ 群と $\mathrm{B}$ 群の被験者背景を表 3 に示す。 $\mathrm{A}$ 群は 31 名（男性 18 名, 女性 13 名, 平均年齢 $78.1 \pm 9.9$ 歳）で, B 群は 29 名（男性 17 名, 女性 12 名, 平 均年齢 $79.6 \pm 8.1$ 歳）であった. A 群と B 群で平 均年齢に有意差は認められなかった。 また被験者 の男女構成や心不全治療薬の差はなかった。 MLHF，MMAS-4, 服用薬剂数, MRCI 以外の変 数は, 従属変数との関係を想定したマッチングに
用いた変数である.ANCOVAの結果を表 4 に示す。 表 4 は介入の有無による 12 力月後の結果（修正 平均）を比較したものである.介入 12 力月後の MLHF と MMAS-4 においては，A群がB 群より 有意に低かった. 介入後 12 力月後の服用薬剂数 と MRCIにおいては，A 群と B 群に有意差は認め られなかった. MLHF, MMAS-4, 服用薬剤数, MRCI の介入前後（すなわち入院時と 12 力月後） の統計量の変動を表 5 に示す。MLHFについては A 群と B 群に有意な改善が認められた. MMAS-4 についてはA 群に有意な低下が認められ，MRCI

表 3 患者背景（入院時）－性別, 心不全治療薬 - 心不全治療薬以外の治療薬の有無

\begin{tabular}{|c|c|c|c|c|c|}
\hline \multirow{2}{*}{ 変数 } & & \multicolumn{2}{|c|}{ A 群 } & \multicolumn{2}{|c|}{ B B 群 } \\
\hline & & $\mathrm{n}$ & 割合 & $\mathrm{n}$ & 割合 \\
\hline \multirow[t]{2}{*}{ 性別 } & 男性 & 18 & $58 \%$ & 17 & $59 \%$ \\
\hline & 女性 & 13 & $42 \%$ & 12 & $42 \%$ \\
\hline$\beta$ 遮断薬（入院時） & & 13 & $42 \%$ & 11 & $38 \%$ \\
\hline angiotensin II receptor blocker: ARB（入院時） & & 19 & $61 \%$ & 18 & $62 \%$ \\
\hline 利尿薬（入院時） & & 19 & $61 \%$ & 18 & $62 \%$ \\
\hline 抗アルドステロン拮抗薬（入院時） & & 4 & $13 \%$ & 3 & $11 \%$ \\
\hline 心不全治療薬以外の治療薬（入院時） & & 30 & $97 \%$ & 29 & $100 \%$ \\
\hline
\end{tabular}

表 4 MLHF, MMAS-4, 服用薬剂数, MRCI の ANCOVA による 12 力月後の修正平均

\begin{tabular}{lccc}
\hline \hline \multicolumn{1}{c}{ 従属変数 } & $\begin{array}{c}\text { A 群 } \\
\text { 平均 } \pm \text { 標準誤差 }\end{array}$ & $\begin{array}{c}\text { B 群 } \\
\text { 平均 } \pm \text { 標準誤差 }\end{array}$ & $P$ 值 \\
\hline MLHF (12 カ月後 $)$ & $46.18 \pm 0.92$ & $54.42 \pm 0.98$ & 0.001 \\
MMAS-4 (12 カ月後 $)$ & $0.36 \pm 0.11$ & $0.94 \pm 0.08$ & 0.001 \\
服用薬剂数 $(12$ 力月後 $)$ & $7.70 \pm 0.19$ & $7.84 \pm 0.21$ & 0.690 \\
MRCI $(12$ カ月後 $)$ & $20.07 \pm 0.64$ & $20.32 \pm 0.68$ & 0.275 \\
\hline
\end{tabular}

共変量は従属変数の入院時值, 平均值は入院時の全体平均（MLHF 51.95, MMAS-4 0.95, 服用薬剤数 7.47, MRCI 20.22）にて算出. MLHF: Minnesota Living with Heart Failure, MMAS-4: Morisky Medication Adherence Scale, MRCI: medication regimen complexity index.

表 5 MLHF, MMAS-4, 服用薬剂数, MRCI の入院時と 12 力月後を比較した統計量の変動

\begin{tabular}{|c|c|c|c|c|c|}
\hline & & $\begin{array}{c}\text { 入院時 } \\
\text { 平均 } \pm \text { 標準偏差 } \\
\text { (最大值・最小值 })\end{array}$ & $\begin{array}{c}12 \text { 力月後 } \\
\text { 平均 } \pm \text { 標準偏差 } \\
\text { (最大值・最小值) }\end{array}$ & $\begin{array}{c}\text { 差 } \\
\text { 平均 } \pm \text { 標準偏差 }\end{array}$ & $P$ 值 \\
\hline \multirow{2}{*}{ MLHF } & $\mathrm{A}$ 群 $(\mathrm{n}=31)$ & $52.04 \pm 11.26(70 \cdot 41)$ & $49.77 \pm 10.97(67 \cdot 41)$ & $-2.27 \pm 1.14$ & 0.005 \\
\hline & B 群（n=29） & $51.91 \pm 4.33 \quad(58 \cdot 45)$ & $51.23 \pm 4.12 \quad(58 \cdot 45)$ & $-0.68 \pm 0.86$ & 0.049 \\
\hline \multirow{2}{*}{ MMAS-4 } & $\mathrm{A}$ 群 $(\mathrm{n}=31)$ & $0.79 \pm 0.88 \quad(3 \cdot 0)$ & $0.33 \pm 0.47 \quad(1 \cdot 0)$ & $-0.46 \pm 0.81$ & 0.017 \\
\hline & B 群（n=29） & $1.11 \pm 0.51 \quad(2 \cdot 0)$ & $0.97 \pm 0.48 \quad(1 \cdot 0)$ & $-0.14 \pm 0.62$ & 0.218 \\
\hline \multirow{2}{*}{ 服用薬剤数 } & $\mathrm{A}$ 群 $(\mathrm{n}=31)$ & $7.34 \pm 2.83 \quad(14 \cdot 3)$ & $7.71 \pm 2.57 \quad(14 \cdot 2)$ & $0.37 \pm 1.41$ & 0.231 \\
\hline & B 群 $(\mathrm{n}=29)$ & $7.61 \pm 1.68 \quad(10 \cdot 5)$ & $7.82 \pm 1.60 \quad(11 \cdot 5)$ & $0.21 \pm 0.50$ & 0.056 \\
\hline \multirow{2}{*}{ MRCI } & $\mathrm{A}$ 群 $(\mathrm{n}=31)$ & $21.76 \pm 8.60 \quad(38 \cdot 8)$ & $21.41 \pm 7.38$ & $0.35 \pm 5.14$ & 0.451 \\
\hline & B 群（n=29） & $18.69 \pm 5.68$ & $19.18 \pm 5.53 \quad(37 \cdot 12)$ & $0.49 \pm 0.86$ & 0.043 \\
\hline
\end{tabular}

Paired $t$-test. MLHF: Minnesota Living with Heart Failure, MMAS-4: Morisky Medication Adherence Scale, MRCI: medication regimen complexity index. 
については B 群に有意な増加が認められた。

\section{考察}

本研究の登録患者は 35 名ずつであったが，解 析できた患者は A 群で 31 名と B 群で 29 名であっ た.この解析できた患者数が登録時の患者数より 減った理由は，死亡，施設へ入所などで当院への 受診ができなくなったためである。心不全治療薬 は, 両群とも ACE 阻害薬/ARB あるいは $\beta$ 遮断 薬の投与が多く, ガイドラインに準じた治療が行 われていた。

統計処理について，ANCOVAによる補正は， 有意差があった共変量に対して実施されるもので はなく，対象となった協働介入群と対照群の背景 に差があれば，比較の公平性の確保を目的に行う べき統計的処理である。本研究の目的は, 被験者 集団を観察し記述することではなく，介入効果を 検証することであり，介入の効果をできるだけ適 性に評価するため，ANCOVAによる介入時の評 価項目に対する補正を行った。

患者 QOL を MLHFで評価した。その結果，A 群に有意な改善が認められた。そこで表 2 の MLHF 各項目の変化を検討したところ，4 項目の み改善していた，具体的項目は，「足の浮腫（む くみ)」が3.16から 2.32へ, 「日中, 椅子に掛け たり，横になって休むことがある」が 3.68 から 3.16 へ，「息切れがする」が 3.52 から 2.68 八，「疲れ やすい，だるい，気力がないと感じる」が 3.32 から 3.00 へと改善していたことが，全体の平均 を低下させた要因であったＡ群における協働介 入は, 開局薬剤師が表 1 の項目について評価し, トレーシングレポートで病院薬剤師へ連絡をして 必要に応じて解決策を協議した。 トレーシングレ ポートは，6力月後の定期報告（33 件）とイべ ント報告 ( 8 件)の合計 41 件であった。このうち， イベント報告の 8 件については，すべて協働介入 を行った。内訳は, 剂形変更 1 例, 用法変更 2 例, 薬剤の中止 2 例, 薬剤の変更 1 例, 投与量の変更 1 例， 1 包化へ変更 1 例であった。開局薬剤師は, 投薬時に副作用や服薬アドヒアランスの評価や介 入だけでなく，患者指導により服薬を継続させる
ことが重要である，すなわち，連携した介入によ る服薬アドヒアランスの改善とともに, 定期的な 評価と患者指導の介入により服薬アドヒアランス の維持ができると考えられる， B 群については， トレーシングレポートによる報告はなかったが QOL の改善が認められた。 B 群では MMAS-4の 有意な低下が認められていないことから, 服薬ア ドヒアランス以外の要素として生活習慣の改善な どが影響したと推察される。これらの結果, A 群 では服薬アドヒアランスを改善し, QOL の改善 へつながったと推察できた，薬郕師は，生活面や 社会面などによる QOL の改善に寄与するよりも， 服薬アドヒアランスの改善に伴う QOL の改善に 貢献できることが示唆された.

しかしながら, MLHF 各項目に関して, 入院時 と 12 力月後で変動がなかった項目も認められた. この結果については，以下のことが考えられる. MLHF の調查方法について, スタッフが項目を読 んで回答を聞き取る方法で，その聞き方も統一で きていなかったため, スタッフの質問の仕方が患 者の回答に影響を及ぼしたことも否定できない． 具体的には，12 カ月後に調查する際に，前回と 比べて変わりありますか，一年前と比べて変わり ありますか，という言葉を各項目で最後につけて いたことが挙げられる。また, 調查期間において, 対象患者の生活環境や家庭環境に変化がなかった ことも要因として考えられる。

服薬アドヒアランスには, 服薬アドヒアランス の評価尺度である MMAS-4 を使用して調査した. その結果, MMAS-4 は A 群の平均值に有意な低 下が認められ， B 群では有意差は認められなかっ たことから，薬剤師の連携した協働介入は服薬ア ドヒアランスを改善することが示唆された。すな わち, 協働介入で服薬確認, 薬効評価と副作用モ ニタリングを行うことが, 患者の服薬アドヒアラ ンスの向上に有用であると言える.

服用薬剂数について, 多剤投与が心不全の入院 と関係しているが, 今回の結果では両群とも有意 な変化はなく, 両群とも平均 7 郕以上であった. これは, 調查患者は高齢者が多いことから幾つか の合併疾患の服薬が必要であり, その結果多剤投 与になったと考えられる.ささらに，入院中に個々 
の患者について必要な処方が確定していたことや 副作用が認められなかったために処方変更がな かったことも要因として考えられる。

最後に，投与レジメンの複雑さを定量化する ツールである MRCIを使って評価した．服薬ア ドヒアランスが悪い患者において MRCIが高い 傾向にあり，特に高血圧治療においては服薬アド ヒアランス不良群で有意に高かった報告がある。 それゆえ，MRCIをできるだけ下げることは，服 薬アドヒアランスの向上のためには必要と考えら れる。今回の結果では，A 群ではベースラインと 比べて 12 力月後では有意な変動はなかったが, $\mathrm{B}$ 群では有意に上昇していた。 このことは，表 1 に示したプロトコールによる薬剤師の協働介入が 服用方法に影響を与えていると考えられた。

以上のことから，本研究にて，心不全患者の外 来患者に対して病院の薬剤師と保険薬局の薬剤師 の協働介入は，服薬アドヒアランスの改善と維持 に寄与し，そのことが QOL の改善につながるこ とが示唆された。

しかしながら，本研究の限界として B 群にお ける保険薬局の薬剤師の介入について検証できな かったこと, 薬剂師以外の多職種の QOLへの介 入について検証できなかったことが挙げられる. よって, 今後は病院薬剤師と薬局薬剤師の協働介 入の手法の分析および多職種連携による QOL の影響を地域全体で検証する必要がある。

\section{謝辞}

本研究にあたり，ご多忙にもかかわらず多大な るご協力をいただきました保険薬局の皆様方に御 礼申し上げます。

\section{利益相反}

開示すべき利益相反はない.

\section{引用文献}

1) Kaneko H, Suzuki S, Goto M, Arita T, Yuzawa Y, Yagi N, Murata N, Kato Y, Kano H, Matsuno S, Otsuka T, Uejima T, Oikawa Y, Sagara K, Nagashima K, Kirigaya H, Sawada H, Aizawa T, Yajima J, Yamashita T, Incidence and predictors of rehospitalization of acute heart failure patients, Int Heart J, 2015, 36, 219-225.

2) Tsuchihashi M, Tsutsui H, Kodama K, Kasagi F, Setoguchi S, Mohr M, Kubota T, Takeshita A, Medical and socioenvironmental predictors of hospital readmission in patients with congestive heart failure, $\mathrm{Am}$ Heart J, 2001, 142, 20A-26A.

3）高井 靖, 梶間勇樹, 西川英郎, 心不全患者に対 する継続した薬剤師の介入が服薬アドヒアラン スに及ぼす影響, 医療薬学, 2017, 43, 388-393.

4) Rector TS, Kubo SH, Cohn JN: Patient's selfassessment of their congestive heart failure: Content, reliability, and validity of a new measure, the Minnesota Living with Heart Failure questionnaire, Heart Fail, 1987, 3, 198-209.

5) Castellucci LA, Shaw J, van der Salm K, Erkens P, Le Gal G, Petrcich W, Carrier M, Self-reported adherence to anticoagulation and its determinants using the Morisky medication adherence scale, Thorombosis Research, 2015, 136, 727-731.

6) George J, Phun YT, Bailey MJ, Kong DC, Stewart K, Development and validation of the medication regimen complexity index, Ann Pharmacother, 2004, 38, 1369-1376.

7）神島滋子, 野地有子, 片倉洋子, 丸山知子, 通院脳 卒中患者の服薬行動に関連する要因の検討 - ア ドヒアランスの視点から, 日本看護科学会誌, 2008, 28, 21-30.

8) de Vries ST, Keers JC, Visser R, de Zeeuw D, HaaijerRuskamp FM, Voorham J, Denig P, Medication beliefs, treatment complexity, and non-adherence to different drug classes in patitnts with type 2 diabettes, J Psychosom Res, 2014, 76, 134-138. 